\title{
Design and Development of Model National Character Building Through Manners Education Based on Regional Culture of North Sumatera
}

\author{
Efendi Napitupulu \\ Department of Electric Education \\ State University of Medan \\ Email: napitupuluefendi@gmail.com \\ Hamonangan Tambunan \\ Department of Electric Education \\ State University of Medan \\ Keysar Panjaitan \\ Department of Mechanical Engineering \\ State University of Medan
}

\begin{abstract}
This study's aim is to look into design of model national character building through manners education based on regional culture. National character building role is to enhance positive behavior for learners to interact with their environment. Manners education should be able to establish the identity of learners through the development of multifaceted potential advantages of nations and multidimensional as it includes the dimensions of nationality and regional culture is currently in the process of finding regional cultural attributes that can be developed into manners learning model based on regional culture of North Sumatera. How to settle character and moral matters of learners as a form of mental revolution is very important to develop. This research approach in the early stages of research and development with reference assessment and and field study design with the culture and customs cases. The field findings show that regional culture attributes relevant to the national character building through manners education who integration with existing lessons by incorporating the values of the character and culture of North Sumatera with "ID-CODE" instructional model.
\end{abstract}

Keywords: Design of Model National character building, Manners education, Regional culture.

\section{INTRODUCTION}

The study of character building becomes important to find models of effective and efficient learning integrated with the existing character education in regional culture. National character building has a very broad urgency and multidimensional. Very spacious as it relates to the development of multi-faceted potential advantages of nations and multidimensional as it includes the dimensions of nationality, is currently in the process of finding regional cultural attributes that can be developed into a manners learning model based on regional culture of North Sumatra.

Character and moral problems of learners, including: (1) capability not optimal yet and readiness of human resources in the school environment in performing the manners learning process based on regional culture; (2) school less than optimal to establish a pattern of behavior of learners in following the process and implementation of mental revolution in the school; (3) understanding and experience of teachers are still lack in choosing manners learning model that effective and efficient in shaping the identity of learners; (5) the manners learning model is still lack based on regional culture in character building of learners as nation. Based on these things interesting for conscientious manners learning model based regional culture in North Sumatera. The outcomes of this research represent an early stage by reviewing how the relevance of the regional culture attributes of North Sumatera in the national character building.

Real conditions that occur at this time uncertainty identity and national character that boils down to (1) disorientation and not internalized yet values of Pancasila as the philosophy and ideology of the nation, (2) the limitations of the policy tools integrated in realizing the values of the essence of Pancasila, (3) shifting the value of ethics in the life of the nation and state, (4) the waning awareness of the cultural values of the nation, (5) the threat of national disintegration, and (6) the weakening of the nation's independence.

\section{National Character Building}

National character building aims to foster and 
develop the character of citizens so as to realize the community's belief in the one and only God, Just and civilised humanity, spirited The unity of Indonesia, spirited Democracy guided by the inner wisdom in the unanimity arising out of deliberations amongst representatives, and Social justice for all of the people of Indonesia. These conducted by (1) Adoption of Pancasila as the philosophy and ideology of the state, (2) Adoption of values and constitutional norms UUD 45, (3) Strengthening national commitment of the Republic of Indonesia (NKRI), (4) Strengthening the values of diversity appropriate the conception of Bhinneka Tunggal Ika (Unity in Diversity), and (5) strengthening the excellence and competitiveness of the nation to the sustainability of society, nation and state of Indonesia in the global context.

Individual character inspired by principles of Pancasila on each part, it can be stated as follows: 1) the character that comes from though the heart, including faith and piety, honest, trustworthy, fair, orderly, law-abiding, responsible, empathize, dare to take risks, unyielding, selfsacrificing and patriotic spirit; 2) the character that comes from thought including, intelligent, critical, creative, innovative, curious, productive, science and technologyoriented, and reflective; 3) The characters that comes from sports/kinesthetic including clean, and healthy, sportive, strong, reliable, resilient, friendly, cooperative, determinative, competitive, cheerful, and persistent; 4) The characters that comes from though the taste and intention including humanitarian, mutual respect, mutual cooperation, togetherness, friendly, respectful, tolerant, nationalist, caring, cosmopolitan (worldwide), give priority to the public interest, patriotism (patriotic), proudly use Indonesia language and product, dynamic, work hard, and work ethic.

Character building can be conducted in the scope of family, the scope of the educational unit, the scope of government, the scope of the civil society and the scope of political public. Education unit is a vehicle for the promotion and development of character made using (a) an integrated approach in all subjects, (b) culture building of education unit, (c) the implementation of curricular and extracurricular, and (d) behaviourhabituation in life at education units environmental.

In the implementation of Indonesian national character education does not stand alone but integration with existing lessons by incorporating the values of the character and culture of Indonesia. National character education can be conducted by noble moral values habituation to learners and familiarize them with habits in accordance with national character. Here grains indicator of national character that can be used as matter for implementing of national character education.

\section{Manners Learning Model}

According to Gustafson (1984), which emphasizes the practical function models is means to facilitate communication, or a regular user (algorithm) that prescriptive for making decision, or planning guidelines for management activities. Further Nadler (1988) explains that a good model is a model which can help the user to understand what is fundamentally a thorough process. Joyce (1992) describes the learning model is a plan or a pattern which is used as a guide in the classroom learning or learning in tutorials and to determine the tools of learning and guide us in designing learning to help learners so that the learning objectives achieved.

Relation to learning model implementation function to directing implementer activity manners learning programs in national character building to design implementation systems that are used in accordance with the scenario of learning that was developed as a guide in the implementation process of manners learning based on culture that effective and efficient.

\section{Cultural Analysis}

The analysis used by Iceberg Theory is to determine the level of understanding and necessary action in anticipation. Iceberg Theory is basically offers analysis techniques to map the presence of symptoms of a problem on several levels, namely:

a. Event, which describes culture indications that can be observed in concrete or can be directly perceived by the public. This indication is followed by action step reactively by the relevant authorities with the problem.

b. Pattern, which describes culture indication be the original cause of their symptoms, abstract and has a recurring pattern of events based on time, conditions or the originator of the problem. This indication is followed by action step responsively by the relevant authorities.

c. Structure, which describes culture indication that the cause is deeper than the symptoms, structured or organized in certain ways. This indication is followed by action step generatively by the relevant authorities that because it is common and can be treated equally relatively or do a logical grouping by categories.

d. Mental models, which describe the character values that are formed in the public perception of an event that can be observed, has a specific pattern, and can be structured in a certain way. Mental models are deepest indicative that can be obtained from this analysis technique. Indications of certain mental models will produce fundamental actionstep by the relevant authorities.

\section{METHOD AND DISCUSSION}

This research uses a research development approach. Made directly with descriptive data collection that are processing and data analysis is inductive (Bogdan and Biklen, 1982). Research development conducted through Research and Development (Research and Development/ R \& D) modified. According to the approach model research and development, the implementation of this research follow the steps, a preliminary survey, planning models, test models, validationmodel and dissemination.

The initial steps of the research conducted to find a character attribute model based regional culture in North Sumatra, the locus of research on cultural analysis Batak 
Toba, Karo, Simalungun and Malay. To get the data implementation of customs (certain cases only).

conducted review of reference and surveys of cultural to the

Preliminary Analysis Manners Learning Model Based on Culture

\begin{tabular}{|c|c|c|c|c|}
\hline \multicolumn{2}{|l|}{ INDICATION } & \multicolumn{3}{|c|}{ ACTION } \\
\hline \multicolumn{2}{|c|}{$\begin{array}{l}\text { Event : } \\
\text { Implementation of manners learning system less } \\
\text { effective and efficient }\end{array}$} & \multicolumn{3}{|c|}{$\begin{array}{l}\text { Reactive : } \\
\text { Designing and developing manners learning modelbased on culture } \\
\text { that is effective and efficient. }\end{array}$} \\
\hline \multicolumn{2}{|c|}{$\begin{array}{l}\text { Pattern : } \\
\text { Appears contradiction between manners learning model } \\
\text { with the national character building }\end{array}$} & \multicolumn{3}{|c|}{$\begin{array}{l}\text { Proactive : } \\
\text { Integrate systematically manners learning model based on culture } \\
\text { with the national character building. }\end{array}$} \\
\hline \multicolumn{2}{|c|}{$\begin{array}{l}\text { Structure : } \\
\text { - Errors in implementing the manners learning process } \\
\text { - Consistency implementation manners learning model } \\
\text { do not have a standardized guidelines } \\
\text { - Mechanisms of manners learning do not run } \\
\text { effectively and efficiently }\end{array}$} & \multicolumn{3}{|c|}{$\begin{array}{l}\text { Generative : } \\
\text { - The scenario construction and implementation mechanisms of } \\
\text { manners learning programs based on culture in the classroom. } \\
\text { - The operational steps preparation of manners learning based on } \\
\text { culture are arranged together in consistent and sustainable. } \\
\text { - Mechanismdevelopment manners learning process based on } \\
\text { culture that effectively and efficiently. }\end{array}$} \\
\hline \multicolumn{2}{|c|}{$\begin{array}{l}\text { Mental Models : } \\
\text { - Learner character have not yet formed } \\
\text { - Improved and awareness of ethical and moral } \\
\text { learners hampered } \\
\text { - The manners learning system has not yet formed a } \\
\text { positive behavior for learners } \\
\text { - Regional culture are not considered as a potential } \\
\text { component for character building of learners }\end{array}$} & \multicolumn{3}{|c|}{$\begin{array}{l}\text { Fundamental : } \\
\text { - Determine the character attributes of the nation } \\
\text { - Determine the competencies to be achieved by the learners } \\
\text { through the manners learning process based on culture in } \\
\text { schools } \\
\text { - Improve the harmonization manners learning process based on } \\
\text { culture with subject matter learning. } \\
\text { - Arrange a learning scheme through the regional culture } \\
\text { component of potential which are integrated with the operational } \\
\text { guidelines for effective and efficient learning. }\end{array}$} \\
\hline \multicolumn{5}{|c|}{ resolved thro } \\
\hline & & & & \\
\hline & & 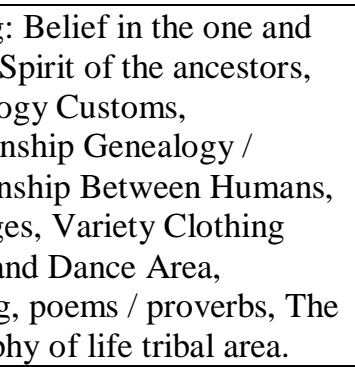 & & \\
\hline
\end{tabular}

\section{Design of National Character Building Attribute Based on Regional Culture of North Sumatra Through Manners Education}

The design of the regional culture-based learning model is developed by combining various existing studentcentered learning models and approaches, such as: social learning is used to introduce contextual learning topics; problem based learning is used to explain the problem of learning and how the problem solving will be done by students; cooperative learning is used to group students; and project based learning is used to provide a specific condition to serve as a student learning object and subsequent exposure and demonstration in front of and / or outside the classroom as discovery learning. The initial design results of the development of culture-based learning model of regional culture, Yin (2009). can be seen as the following figure 1: 


\section{“ID-CODE" Model:}

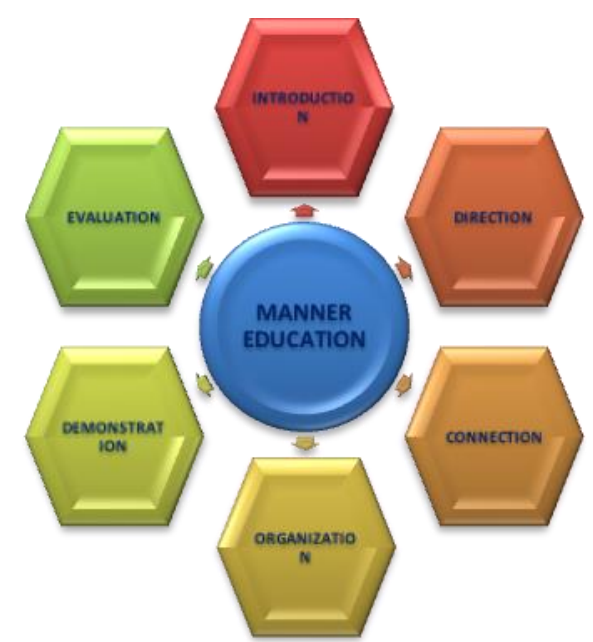

Figure .1: Initial Design of Culture-Based Learning Model

The initial design result of the interactive culturebased learning model as shown above is called "ID-CODE" with six (6) stages of learning activities. The stages of learning activities based on the model "ID-CODE" can be described as follows: Introduction (I) : Creating an effective early learning atmosphere that enables learners to follow learning well; Explain the learning objectives; Asking the previous material and its relation to the learners will learn; Delivering the range of material to be learned by students. Direction (D) : Giving reference so that students can follow the learning process; Attract attention and generate curiosity of learners; Directing learners to follow the learning stages related to learning objectives. Connection (C) : Conditioning learners and learning environments to be actively involved in learning activities; Opening space for learners to participate actively in learning activities; Involve learners looking for information on the subject matter theme; Facilitating learners to be able to observe the phenomenon or object of material through pemberian tasks, discussions, and others to bring new ideas both orally and in writing. Organization (O) : Organize students, resources/materials, time and space of learning; Creating a democratic learning atmosphere; Delivering learning programs; Creating educational and characteristic attitudes through manners education based on regional culture; Describe the learning activities in accordance with the learning stages; Describe an outline of facts, concepts, procedures, and generalizations. Demonstration (D) : Plan follow-up activities; Delivering a lesson plan; Facilitating learners to present their creations, individual or group work; Doing exercises and observations; Provide opportunities for learners to undertake an activity related to cultural aspects relevant to the learning objectives and daily life in the community; Finding and resolving behavior that causes problems; Transmit cultural values with the learning process and self-actualization of learners; Establish behavior in accordance with moral values, rules and ethics of society as the character of the nation. Evaluation (E) : Together with the learners and / or themselves make the conclusion of the lesson; Conduct assessment and/or reflection on activities that have been implemented consistently and programmatically; Provide feedback on learning processes and outcomesat the next meeting.

\section{CONCLUSION}

1. National character building can be conducted through manners learning based on regional culture who integration with existing lessons by incorporating the values of the character and culture of North Sumatra.

2. Regional culture attributes that can be used as learning subject, including: Belief in the one and only God and the ancestral spirits, Values and Customs Typology, Cohesiveness/ Kinship Genealogy/ Patterns of relationship Between People, Language and Regional Literacy, Traditional Clothing, Art and Regional Dances, Poem/ Proverb, Tales and Folklore, Mindset/philosophy tribes living area of North Sumatra.

3. The initial design result of the interactive multimediabased learning model as shown above is called "IDCODE" with six (6) stages of learning activities. The stages of learning activities based on the model "IDCODE": Introduction, Direction, Connection, Organization, Demonstration, and Evaluation.

\section{REFERENCE}

[1] Bogdan, R \& Biklen, S.K. (2007). Qualitative Research for Education: An Introduction to Theories and Methods, 5th Edition : Pearson

[2] Edgar, A and Peter, S. 2005. Cultural Theory: The Key Concepts. 2nd edition. NY: Routledge.

[3] Gustafson, K.L. 1981. Survey of Instrucyional Development Models. Syracuse, NY: Eric IR Document.

[4] Joyce, B. R. (1991). Models of teaching. Fourth Edition. BostonLondon- Toronto- Sydney- Singapore: Allyn and Bacon Pulishers.

[5] Lincoln Y and Guba, EG. (1985) Naturalistic Inquiry, Sage Publications, Newbury Park, CA.

[6] Miles, MB \& Huberman, AM (1994) Qualitative Data Analysis (2nd edition). Thousand Oaks, CA: Sage Publications.

[7] Morgan, D. (1988). Focus Groups as Qualitative Research. Qualitative Research Methods Series. 16. Thousand Oaks, CA: Sage.

[8] Nadler, L. 1988. Designing Training Program.Massachussetts : Addison-Wesley Publishing Company.

[9] Williams, R. (1981). Culture. London: Fontana.

[10] Yin, R. K. (2009). Case study research: Design and methods (4 ed.). Los Angeles, CA: Sage. 